inauguration of Robert McLaughlin as president of Herkimer County Community College.

\section{IMPROVEMENTS FOR ACADEMIC LIBRARIANS}

The College, University and Research Library Section (CURLS) of the California Library Association adopted a position paper at its Fresno meeting on October 24, calling for "full faculty status [for librarians] with ranks appropriate to their backgrounds and assignments." The paper also called for equivalent salaries; sufficient clerical support for professional assignments; a workload to include time for independent research; sabbatical and other leaves; eligibility for tenure prefaced by contractual employment; promotion on the basis of standards and criteria used for professorial classes independent of administrative duties; access to grants, fellowships and research funds; a grievance procedure similar to that of other faculty members; and membership in the Academic Senate or equivalent body. "No librarian, currently employed, shall be demoted or suffer loss of annual income through application of the new standards," reads the "grandfather clause" accompanying the change.

A very effective joint presentation of the above position was made by Marc Gittelsohn of UC Berkeley and Fay Blake of UCLA. The motion was approved without opposition when Loren Owings (UC Davis) called the question. It now goes to the CLA Board of Directors for its approval. University Librarian J. Richard Blanchard (UC Davis) moved that the adopted motion be called to the attention of the Coordinating Council for Higher Education, the chief officers of academic institutions in California, and other state committees as appropriate. This, too, was approved without opposition.

Obviously, it will take a sustained effort to implement the position. This effort is aided by the similar position adopted by the Academic Senates of the California State Colleges at their October 20 meeting. There is also a similar movement in other parts of the nation supporting this move, as witnessed by City University of New York's Harold D. Jones in his report of "How the East Was Won."Charles Shain.

\section{CAN YOU HELP WITH DONATIONS OF BOOKS FOR ASIAN INSTITUTIONS?}

Can you help The Asia Foundation provide special useful collections such as basic science books for the new Ahmedabad Science Center in India, management books for the Management Development Center in East Pakistan, law books for Seoul National University? Books in excellent condition, in all college and adult level disciplines, can be used. Titles in the physical sciences should carry publication date of 1955 or later, in the social sciences and humanities, 1950 or later. Literary classics and anthologies of any date are welcome. Small quantities may be mailed by "Special 4th Class Rate-Books" directly to BOOKS FOR ASIAN STUDENTS, 451 Sixth St., San Francisco, Calif. 94103. Book donations to The Asia Foundation are tax deductible.

\section{INTERLIBRARY COOPERATION}

A leaflet prepared by the Ad Hoc Joint Com. mittee on Cooperative Activities, entitled "Interlibrary Cooperation" is available from the Public Library Association of ALA. Single copies are free; bulk orders will be filled at the following rates: 25 copies-\$1.; 100 copies —\$3.; 1000 copies-\$20.

\section{0,000 COLOR SLIDE LIBRARY OF WORLD ART A SINGLE UNIT INSTALLATION-READY FOR USE \\ ... prepared by our art history department spe- cifically for bibrary lending or reference from the world's largest collection (over 100,000 archive).}

7 A MONOLITHIC COLLECTION (comprising an imposing. harmonious whole) : covers all important works in Western and Oriental Art (all major museums represented).

(1) ALL PERIODS COVERED: from paleolithic to present time.

II ALL MEDIA INCLUDED: architecture, sculpture. painting and minor arts.

리 LARGE MODERN SECTION: all movements.

- HISTORICAL CLASSIFICATIONS: all slides are coded (dates, periods, genre, iconography, style, etc.).

A collection resulting from more than 12 years of research and compilation-now ready for library installation.

An approved source-already in use in many public libraries. This major compilation can be acquired in 2 sections to meet budget requirements. Superior quality ... coded for refiling SMALLER LIBRARY COLLECTIONS AVAILABLE. Write for details and CATALOG $\mathrm{L}-4$

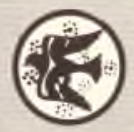

AMERICAN LIBRARY COLOR SLIDE CO., INC. 305 East 45 th $S t$ New York, N.Y. 10017 